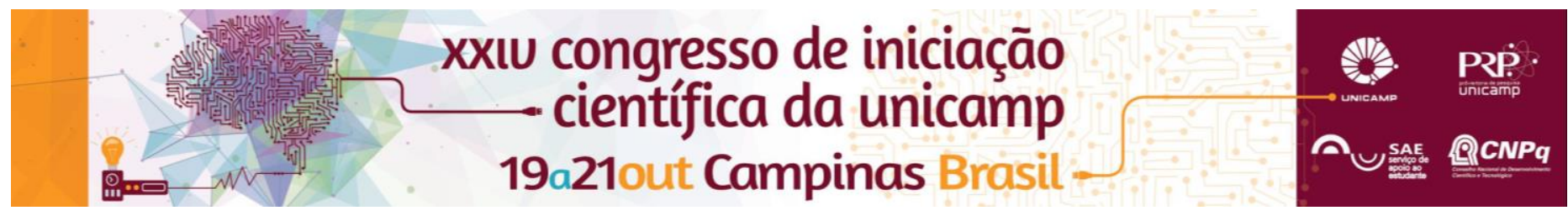

\title{
Mapeamento e análise do uso da terra nas Áreas de Preservação Permanente (APP) no município de Indaiatuba (SP)
}

\section{Letícia de Sousa Araújo*, Lindon Fonseca Matias}

\section{Resumo}

O município de Indaiatuba localiza-se a $90 \mathrm{~km}$ de distância da capital do Estado de São Paulo e possui $311,55 \mathrm{~km}^{2}$ (SEADE, 2015). Apresenta taxa de urbanização de 98,99\% e população de 225.974 habitantes (SEADE, 2015). É detentora de um PIB de $\mathrm{R} \$ 6.163,1$ milhões, PIB per capta de $\mathrm{R} \$ 29.251,14$ e um IDHM de 0,788 (SEADE, 2012 e 2010). Este passou a chamar a atenção por seu rápido crescimento populacional que, nos últimos 45 anos, alcançou taxas médias de crescimento acima da média de Campinas, principal município da região, e de toda Região Metropolitana. A acentuada expansão de sua mancha urbana que vem alterando o uso da terra, bem como expandindo as formas de uso da terra tipicamente urbanas, traz como consequência o avanço sobre o meio natural, que inevitavelmente gera impactos socioambientais. Sendo assim, realizou-se o mapeamento e análise do uso da terra nas Áreas de Preservação Permanente (APP), que são áreas que desempenham importante papel ambiental, almejando descobrir se existem impactos socioambientais acarretados por essa intensa expansão urbana e, por meio dos resultados obtidos, contribuir para a construção de um conhecimento mais abalizado sobre a dinâmica socioambiental e urbana de Indaiatuba.

\section{Palavras-chave:}

Áreas de Preservação Permanente, Geoprocessamento, Indaiatuba

\section{Introdução}

A pesquisa teve como objetivo central a execução do mapeamento das Áreas de Preservação Permanente (APP) no município de Indaiatuba e posterior análise do uso e ocupação da terra. Assim, buscou-se revelar seus atuais usos e constatar a adequação com a legislação vigente, isto é, com o novo Código Florestal, Lei $\mathrm{n}^{\circ}$ 12.651 de 25 de maio de 2012, apontando os principais impactos socioambientais e correlacionando com a expansão da mancha urbana que se deu a partir da década de 1970. Em adendo ao mapeamento das APP, para um estudo mais completo, foi acrescido também o mapeamento das planícies aluviais (PA), de modo a constatar sua situação de uso e ocupação.

\section{Resultados e Discussão}

A metodologia utilizada consistiu em quatro etapas: revisão bibliográfica, atividades de geoprocessamento, trabalho de campo e análise de resultados. A partir destes procedimentos, foram obtidos os seguintes resultados:

- Verificou-se que as APP constituem 15,95\% (49,93 $\left.\mathrm{km}^{2}\right)$ e as PA $5,07 \%\left(15,87 \mathrm{~km}^{2}\right)$ da área do município. É importante destacar que há sobreposição das APP e das PA, por isso a contabilização da área total equivale a $18,27 \%\left(57,20 \mathrm{~km}^{2}\right)$.

- Constatou-se que $54,1 \%\left(8,58 \mathrm{~km}^{2}\right)$ das PA estão contidas nas áreas que são determinadas pela legislação como APP. Em geral nota-se que a maioria das APP e das PA não se encontram preservadas, uma vez que, em ambos os casos, a taxa de inadequação situa-se em mais de $50 \%$, chegando a $53,98 \%$ quando levado em conta as duas áreas em conjunto.

- Os usos predominantes de ocupação da terra são usos típicos do meio rural em ambas as áreas: pastagem $(27,34 \%)$, floresta $(21,59 \%)$ e campestre $(18,27 \%)$. Destaca-se que as pastagens constituem uma classe de uso e ocupação inadequadas para as APP e, também, de acordo com os critérios adotados, para as PA.

- A maioria dos usos que estão em situação de não adequação com a legislação são usos rurais, estes correspondem a $64,51 \%$ dos usos inadequados.

- As APP correspondem a 10,76\% $\left(11,05 \mathrm{~km}^{2}\right)$ da área urbanizada do município $\left(102,71 \mathrm{~km}^{2}\right)$, as planícies $2,99 \%$ e, em conjunto, correspondem a $11,73 \%$.

- Em relação aos usos urbanos, o uso residencial corresponde a $7,73 \%\left(2,39 \mathrm{~km}^{2}\right)$ dos usos considerados em não conformidade com a legislação $e$, detalhadamente, dentro do uso residencial, $1,95 \mathrm{~km}^{2}$ correspondem aos condomínios e loteamentos horizontais, ou seja, $81,59 \%$ de todo o uso residencial. Muitos desses condomínios e loteamentos horizontais localizam-se, principalmente, muito próximos as APP, em geral no seu entorno: próximos aos corpos d'água, rios e lagoas, utilizando-os como atrativos para o consumo, para aumentar seu valor de troca.

\section{Conclusões}

Apesar da conhecida importância das APP e PA, no município em questão a maior parte destas áreas não estão preservadas, isto é, não estão em conformidade com a legislação, fato que prejudica o pleno cumprimento de suas funções naturais. Assim, é importante que a gestão e o planejamento urbano e ambiental sejam realizados de maneira integrada.

\section{Agradecimentos}

Os autores agradecem à Fapesp (Processo 2014/231368) pela concessão da bolsa de iniciação científica que subsidiou a realização desta pesquisa.

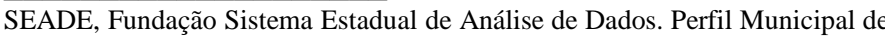
Indaiatuba. Disponível em: <http://www.imp.seade.gov.br/>. Acesso em: Maio 2016. 